\title{
Numerical simulation of elastoplastic contact of heavy-loaded spiroid gears
}

\author{
Alexander Sannikov \\ Institute of Mechanics, Kalashnikov Izhevsk State Technical University, Izhevsk, Russia, Alex1_87@mail.ru
}

\begin{abstract}
The paper presents the analysis of heavy-loaded low-speed multi-pair spiroid gears under the effect of elastic contact, bending and shearing, and elastoplastic contact interaction of spiroid gearwheel teeth and spiroid worm threads. The main stages of the developed algorithm for analysis of load distribution and plastic strain of flanks with account of elastic and elastoplastic contact conditions, multi-pair contact and macro-roughnesses on flanks are described in short. At elastoplastic contact the zones of plastic contact on flanks of spiroid gearwheel teeth are determined and the value of plastic strain is analyzed. The flanks of the spiroid gearwheel teeth and worm threads are represented in the algorithm as the set of segments (cells) with coordinates of centers determined with account of the analyzed factors that influence the load distribution in spiroid gearing. These factors are the errors of manufacturing and (or) assembly, microroughnesses, and deformations of spiroid gear supports. The paper gives the numerical results of research of the real spiroid gears of gearboxes for pipeline valves (PV) at elastic and elastoplastic contact represented as summary tables and diagrams of contact stress distribution along contact areas and of plastic strain, that show the workability of the algorithm. The presented numerical results of the algorithm functioning are well agreed with the experience of operation of spiroid gears and can be applied for analysis of load-carrying capacity of spiroid gears.
\end{abstract}

\section{Introduction}

Spiroid gears are well-proven in heavy-loaded low-speed operation of pipeline valve drives under the action of short-term increased loads and practically instant peak overloads which has been multiply confirmed by research and operation experience of gearboxes designed at the scientific school headed by Prof. V. I. Goldfarb [15]. Spiroid gears have a number of advantages [1-9] as compared to cylindrical worm gears that have been commonly applied [17-19] in the mentioned drives:

- high theoretical contact ratio - up to $10 \%-12 \%$ of the total number of gearwheel teeth can be simultaneously meshed;

- $\quad$ high integrity of contacting surfaces;

- favorable arrangement of contact lines - practically orthogonal with regard to the vector of relative speed in the gear;

- high speed of displacement of contact lines along operating flanks;

- lower sensitivity to manufacturing and assembly errors;

- possibility to adjust easily the backlash in the meshing.

Practice of operation of PV gearboxes (Fig. 1) shows that even at the first cycles of operation the traces of plastic strain appear on flanks that influence the stressstrain state (SSS) of the gear and, as a consequence, its load-carrying capacity. This effect irreversibly breaks the initial geometry of teeth and leads to redistribution of the load transmitted by teeth.

The relevant quantitative account of plastic strain (Fig. 2) of tooth flanks is necessary when assessing the SSS of heavy-loaded gears. In [12-13] the algorithm of such an assessment is suggested. This paper considers the results of assessing the SSS of a number of real spiroid gears of pipeline valve gearboxes by means of this algorithm.

\section{Algorithm for analysis of the stress- strain state of elastoplastic contact of heavy-loaded spiroid gears}

At present time the common approach to analyze the loaded systems (including gears) is the finite-element method [14-16]. Practice of applying this approach shows that it is convenient in those cases when the design solution is already accepted or almost ready. Its refining by considering multiple versions of gears is therefore not suitable, since the analysis at the necessary degree of accuracy takes too much time. That is why, more efficient methods of analysis of various structural elements are developed [7, 10, 11, 13].

Our developed algorithm applies the discrete representation of tooth flanks as the set of elementary areas (cells) with coordinates of centers (nodes) preliminary calculated with account of necessary modifications and inevitable manufacturing errors [2]. 
The loaded gear represents a discretely loaded system in which the joint displacement of cells of worm threads and gearwheel teeth and the condition of force equilibrium are described by the following system of equations:

$$
\left\{\begin{array}{l}
w_{k m}+S_{0 k m}-\Delta_{\varphi 2_{k m}}=0 ; \\
\sum_{D} F_{k^{\prime} m^{\prime}} \breve{r}_{2 k^{\prime} m^{\prime}}-T_{2}=0 ;
\end{array}\right.
$$

where $w_{k m}$ is the elastoplastic displacement; $S_{0 k m}$ is the initial clearance (prior to analysis of load distribution) between the $\mathrm{km}^{\text {th }}$ cells of the surface, $\Delta_{\varphi 2 \mathrm{~km}}$ is the relative displacements of the $\mathrm{km}^{\text {th }}$ cells as a result of approaching the gear elements at gear loading, $\check{r}_{2 k^{\prime} m}$, is the arm of action of the force $F_{k^{\prime} m}$, applied at the $k^{\prime} m$, th cell relative to the gearwheel axis, $T_{2}$ is the assigned torque at the spiroid gearwheel.

The number of equations of the pointed system (1) is unknown beforehand and is specified during calculation. It is also efficient to specify all the sought parameters during calculation: the contact area $D$, the value $\Delta_{\varphi 2}$ of approaching the elements and the value of discretely applied forces.

The system (1) is usually solved in the elastic statement $[10,11,13]$. In order to account plastic contact deformations, the following iterative algorithm of analysis is presented:

1) input of initial data: initial clearances $S_{0 k m}$, physical and mechanical properties of materials of elements, and torque $T_{2}$;

2) assignment and calculation of data for the first approximation (the first iteration): the approach of elements, the set of loaded (embedded) cells, and forces at these cells.

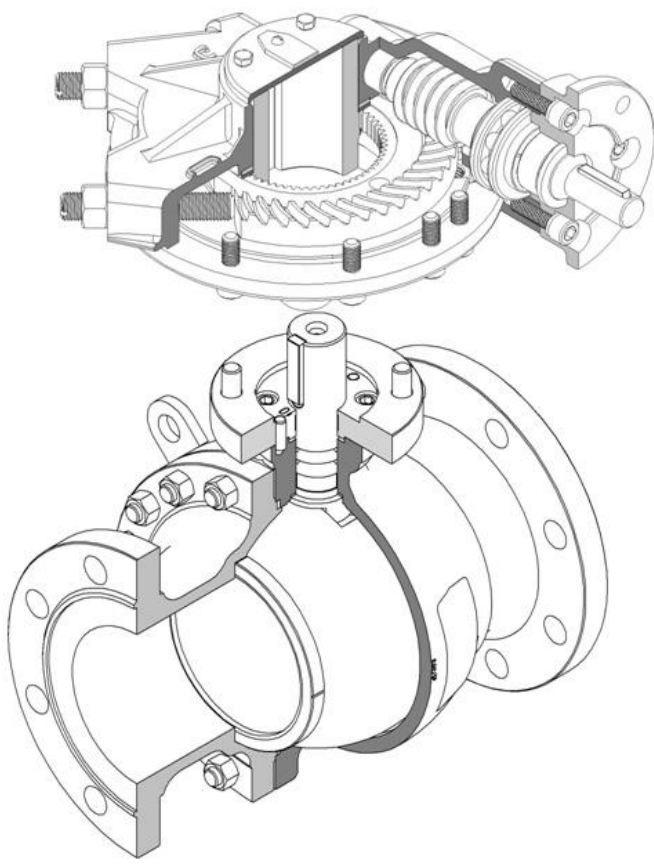

Fig. 1. Spiroid gearbox on pipeline valve (PV).

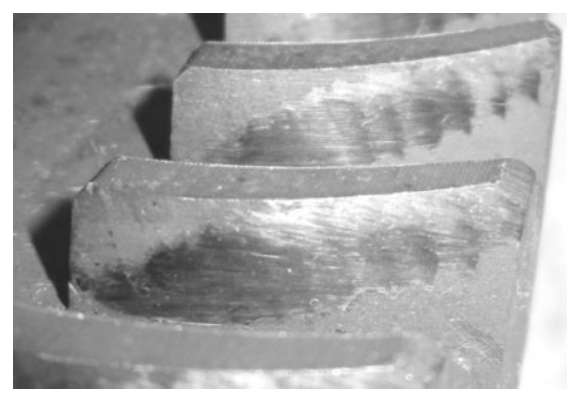

Fig. 2. Contact pattern on the right flank of spiroid gearwheel tooth.

The consequent steps of the algorithm are related both to the first and to all the next iterations.

3) calculation of elastic displacement of cells due to forces acting in them;

4) calculation of clearances/embedding (further - discrepancies $\xi$ ) that appear between teeth after account of elastic and elastoplastic displacements at the assigned approaching. Correction of the value of approaching depending on the average discrepancy $\xi_{a v}$;

5) correction of the contact area $D$; those cells are added in which the value of discrepancy became negative (the design embedding took place, the cell came into contact and began transmitting the torque);

6) correction of forces in cells depending on the value of discrepancy. Cells with the zero force are excluded from the contact area with the consequent correction of the forces remaining to provide the equilibrium condition (the last equation in the system (1));

7) analysis (correction) of plastic strain $w_{p}$ in cells where the contact stress $\sigma_{H}$ exceeded the allowable one $\left[\sigma_{H}\right][21]$, in this case, forces at these cells are corrected (decreased), that is, calculated according to $\left[\sigma_{H}\right]$ and the area of the cell;

8) approximation of the final number of strain areas that appeared on tooth flanks;

9) checking the condition of finalizing the algorithm according to the chosen criterion of calculation accuracy and the completed task of SSS analysis.

As it can be observed, during the algorithm running one can successively specify the components of displacement of cells under load - the elastic component (step 3) and the plastic one (step 7).

\section{Results of numerical simulation}

Parameters and load characteristics of spiroid gears of PV gearboxes chosen for numerical analysis are given in Table 1 . The peak torque $T_{2 p e a k}$ acting practically instantly or in statics is taken as the torque $T_{2}$. Numerical analysis was carried out with account of the pitch error $f_{x p}$ of spiroid worm threads, and the error of spiroid gearwheel profile due to the presence of faceting $f_{\text {fac }}$.

Results of simulation are summarized in Tables 2-4, which present the values of maximum contact stress $\sigma_{H \max }$ along all instant contact areas and values of torques $T_{2 a r r}$ at instant contact areas on the right flank in one of meshing phases, and the number of loaded cells in the 
calculation of $N_{\text {load }}$. Figs. 3-16 show the distribution of contact stresses and plastic strain at instant contact areas on the right tooth flank of the spiroid gearwheel in one of arbitrary phases of operation, where $r$ is the radius of the spiroid gearwheel, $h$ is the tooth height of the spiroid gearwheel ( 0 is the tooth root). Figures a) show contact stresses calculated with account of the elastic character of contact only, and figures b) show contact stresses calculated at elastoplastic contact with account of the plastic strain of tooth surfaces.

Table 1. Gear parameters.

\begin{tabular}{|l|c|c|c|}
\hline \multicolumn{1}{|c|}{ Parameter } & \multicolumn{3}{c|}{ Value } \\
\hline Gearbox model & $\begin{array}{c}\text { RZA-S- } \\
2000\end{array}$ & $\begin{array}{c}\text { RZA-S- } \\
32000\end{array}$ & $\begin{array}{c}\text { RZAM-S- } \\
500\end{array}$ \\
\hline$a_{w}, \mathrm{~mm}$ & 60 & 130 & 28 \\
\hline$m_{x l}, \mathrm{~mm}$ & 2.75 & 4.999 & 3.385 \\
\hline$z_{2} / z_{1}$ & $46 / 1$ & $55 / 1$ & $22 / 3$ \\
\hline$d_{a l}, \mathrm{~mm}$ & 42 & 85 & 40.5 \\
\hline$D_{e 2} / D_{i 2}, \mathrm{~mm}$ & $175 / 138$ & $290 / 400$ & $92 / 120$ \\
\hline$h_{a 1} / h_{f 1}$ & $1 / 1.2$ & $1 / 1.2$ & $1 / 1.2$ \\
\hline$\alpha_{n l} / \alpha_{n l}$ & $11.8^{\circ} / 28.8^{\circ}$ & $11.9 / 29.9$ & $13.9 / 26.5$ \\
\hline$T_{2 p e a k}, \mathrm{Nm}$ & 4000 & 64000 & 1000 \\
\hline $\begin{array}{l}\text { Material of } \\
\text { gear pair }\end{array}$ & $(0.4 \% \mathrm{C},<1.5 \% \mathrm{Cr}), 45 \ldots .50 \mathrm{HRC}$ \\
\hline$\left[\sigma_{H}\right][3]$, MPa & \multicolumn{4}{|c|}{1900} \\
\hline Note: \\
$a_{w}-$ centre distance; \\
$m_{x l}-$ axial module of the worm; \\
$z_{2} / z_{1}-$ number of gearwheel teeth / worm threads; \\
$d_{a 1}-$ external diameter of the spiroid worm; \\
$D_{e 2} / D_{i 2}-$ external and internal diameters of spiroid gear- \\
wheel; \\
$h_{a l} / h_{f 1}-$ addendum/dedendum factor; \\
$\alpha_{n r} / \alpha_{n l}-$ profile angles of the right/left flanks.
\end{tabular}

\subsection{Results of numerical simulation for gearbox model RZA-S-2000}

Table 2. Gearbox model RZA-S-2000

\begin{tabular}{|l|c|c|c|c|}
\hline \multicolumn{1}{|c|}{ Parameter } & \multicolumn{2}{|c|}{ Elastic model } & \multicolumn{2}{c|}{ Elastoplastic model } \\
\hline$\sigma_{\text {Hmax }}, \mathrm{MPa}$ & 2380 & 2800 & 1900 & 1900 \\
\hline & 964 & 1434 & 959 & 1377 \\
& 1134 & 1294 & 1129 & 1296 \\
$T_{2 a r r}, \mathrm{Nm}$ & 1088 & 863 & 1093 & 896 \\
& 814 & 409 & 819 & 431 \\
\hline$N_{\text {load }}$, pieces & 2648 & 2594 & 2685 & 2737 \\
\hline$f_{x p}, \mu \mathrm{m}$ & - & 100 & - & 100 \\
\hline
\end{tabular}

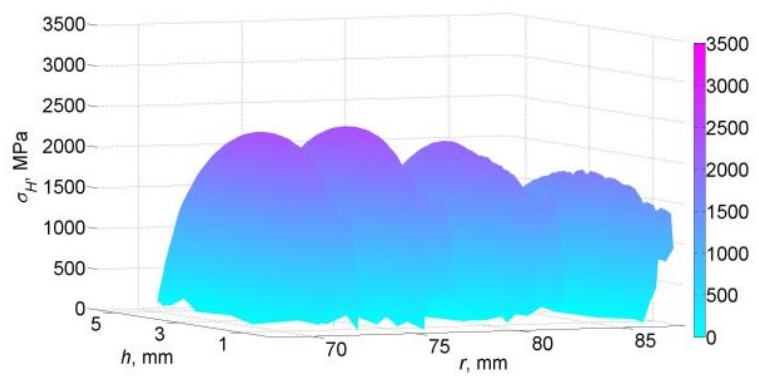

a)

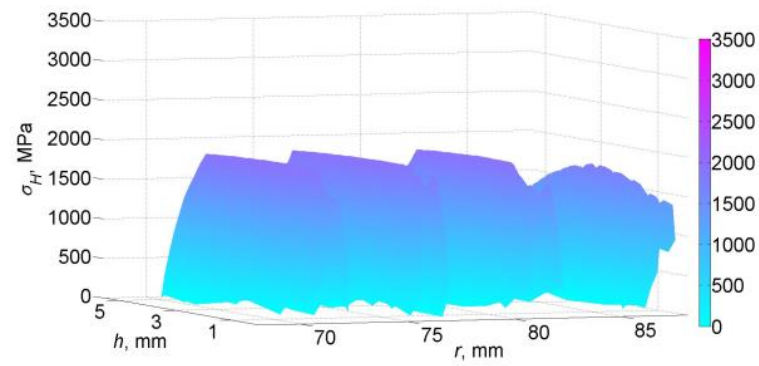

b)

Fig. 3. Distribution of $\sigma_{H}$ in the gear of gearbox RZA-S-2000.

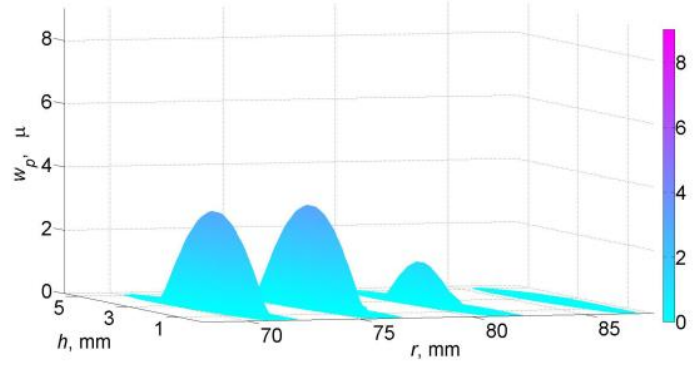

Fig. 4. Distribution of $w_{p}$ in the gear of gearbox RZA-S-2000.

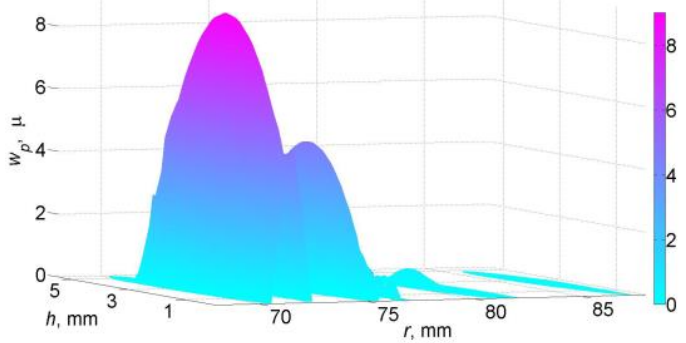

Fig. 5. Distribution of $w_{p}$ in the gear of gearbox RZA-S-2000 for $f_{x p}=100 \mathrm{mcm}$.

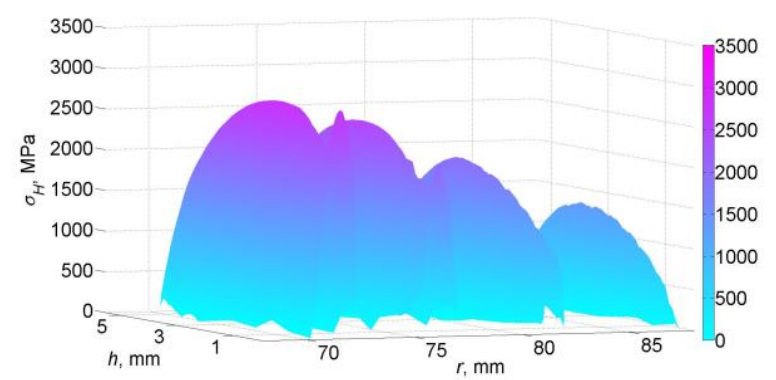

a)

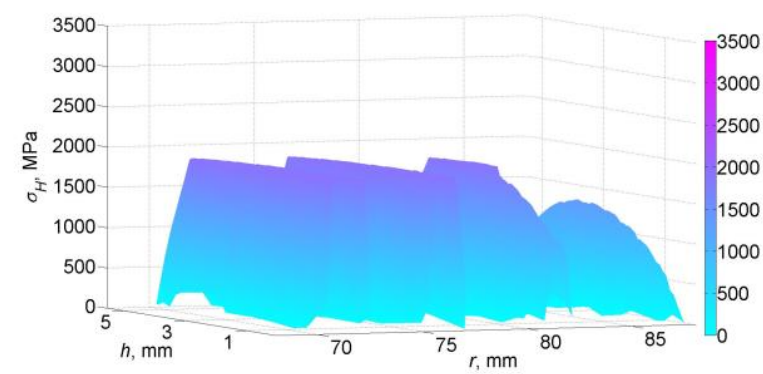

b)

Fig. 6. Distribution of $\sigma_{H}$ in the gear of gearbox RZA-S-2000 for $f_{x p}=100 \mathrm{mcm}$. 


\subsection{Results of numerical simulation for gearbox} model RZA-S-32000

Table 3. Gearbox model RZA-S-32000.

\begin{tabular}{|c|c|c|c|c|}
\hline Parameter & \multicolumn{2}{|c|}{ Elastic model } & \multicolumn{2}{c|}{ Elastoplastic model } \\
\hline$\sigma_{\text {Hmax }}, \mathrm{MPa}$ & 2910 & 3356 & 1900 & 1900 \\
\hline & 9269 & 13848 & 9109 & 12766 \\
& 10834 & 14027 & 10607 & 13356 \\
& 1159 & 12705 & 11430 & 12685 \\
$T_{2 \text { arr }}, \mathrm{Nm}$ & 11483 & 10264 & 11522 & 10816 \\
& 11152 & 7911 & 11336 & 8577 \\
& 9670 & 5245 & 9996 & 5800 \\
\hline$N_{\text {load }}$, pieces & 4874 & 4831 & 5440 & 5753 \\
\hline$f_{x p}, \mu \mathrm{m}$ & - & 150 & - & 150 \\
\hline
\end{tabular}

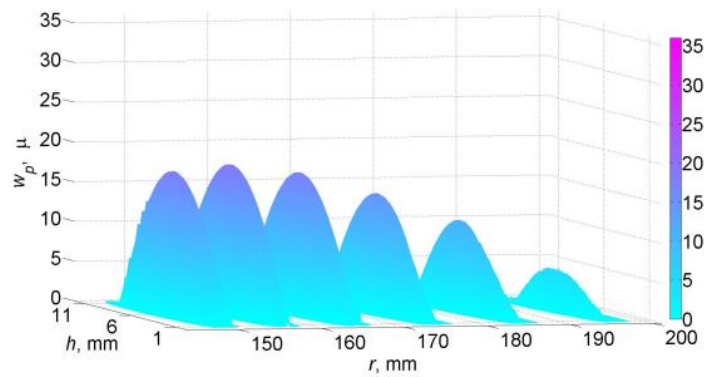

Fig. 7. Distribution of $w_{p}$ in the gear of gearbox RZA-S-32000.

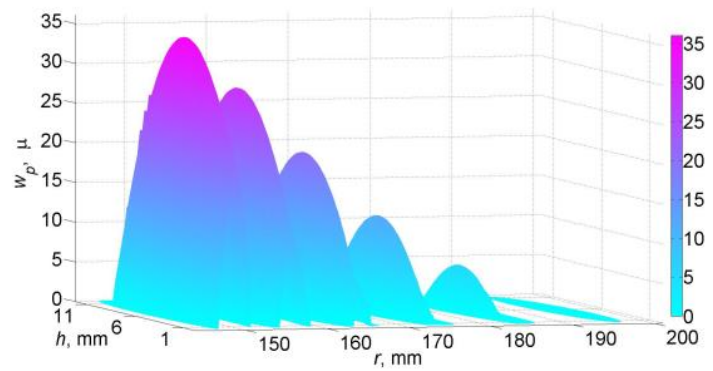

Fig. 8. Distribution of $w_{p}$ in the gear of gearbox RZA-S-32000 for $f_{x p}=100 \mathrm{mcm}$.

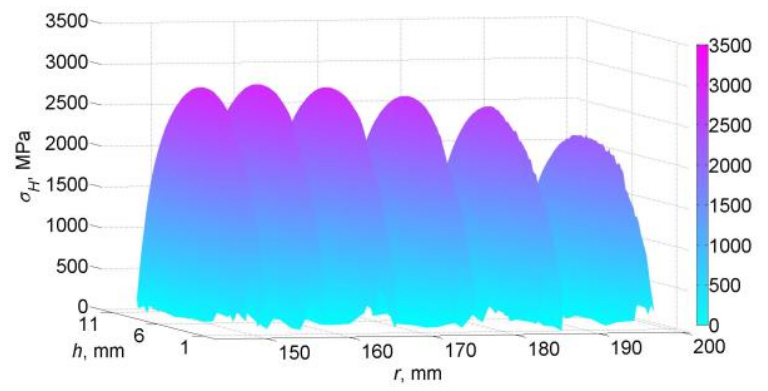

a)

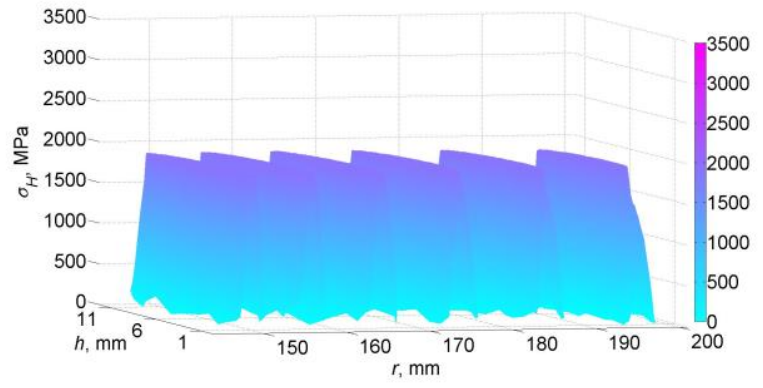

b)

Fig. 9. Distribution of $\sigma_{H}$ in the gear of gearbox RZA-S32000 .

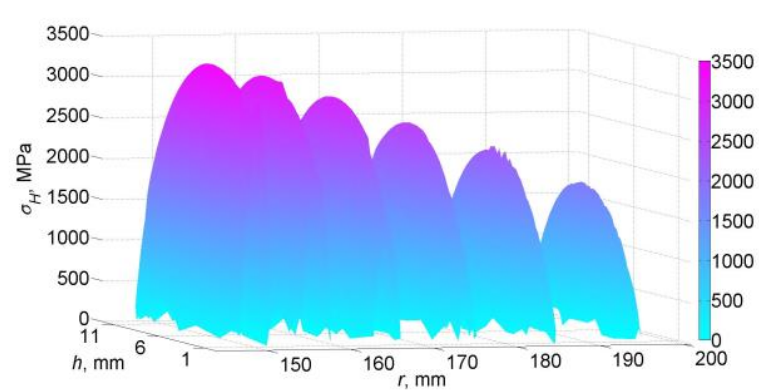

a)

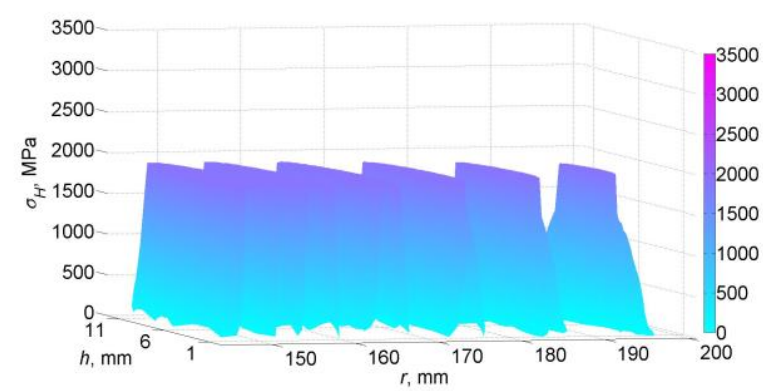

b)

Fig. 10. Distribution of $\sigma_{H}$ in the gear of gearbox RZA-S32000 for $f_{x p}=100 \mathrm{mcm}$.

\subsection{Results of numerical simulation for gearbox model RZAM-S-500}

Table 4. Gearbox model RZAM-S-500.

\begin{tabular}{|l|c|c|c|c|c|c|}
\hline \multicolumn{1}{|c|}{ Parameter } & \multicolumn{3}{c|}{ Elastic model } & \multicolumn{3}{c|}{ Elastoplastic model } \\
\hline$\sigma_{\text {Hmax }}, \mathrm{MPa}$ & 2756 & 5113 & 8030 & 1900 & 1900 & 1900 \\
\hline & 626 & 34 & 640 & 619 & 27 & 672 \\
$T_{\text {2arr }}, \mathrm{Nm}$ & 375 & 722 & 360 & 381 & 714 & 328 \\
& & 244 & & & 259 & \\
\hline$N_{\text {load }}$, pieces & 614 & 608 & & 663 & 675 & \\
\hline$f_{x p}, \mu \mathrm{m}$ & - & 100 & - & - & 100 & - \\
\hline$f_{\text {fac }}, \mu \mathrm{m}$ & - & - & 100 & - & - & 100 \\
\hline
\end{tabular}

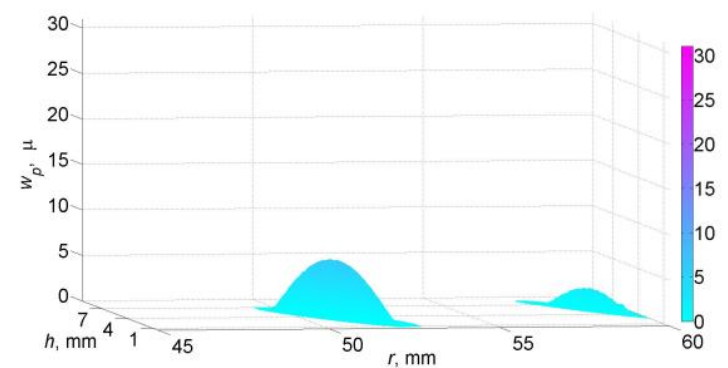

Fig. 11. Distribution of $w_{p}$ in the gear of gearbox RZAM-S-500

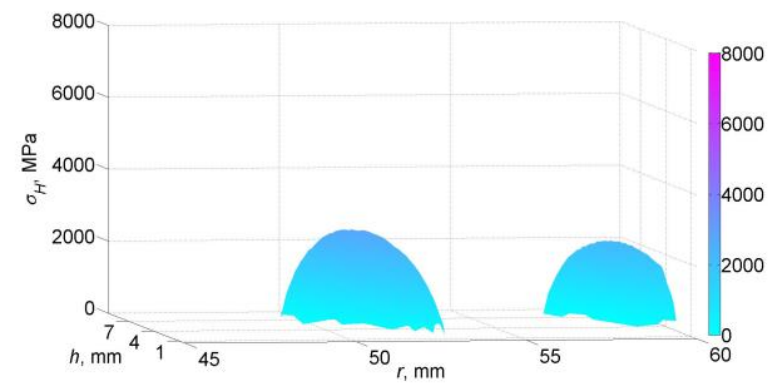

a) 


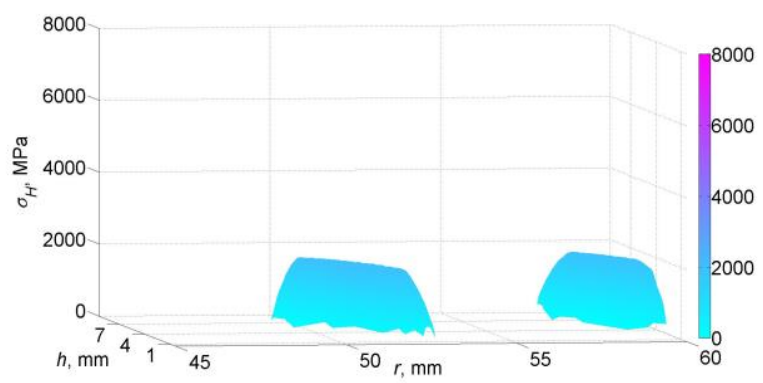

b)

Fig. 12. Distribution of $\sigma_{H}$ in the gear of gearbox RZAM-S500

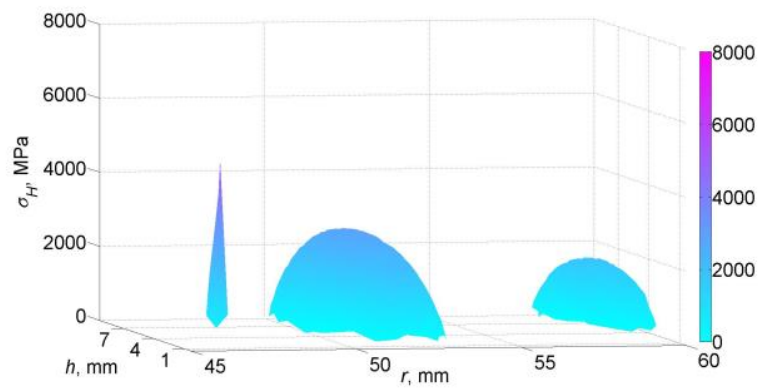

a)

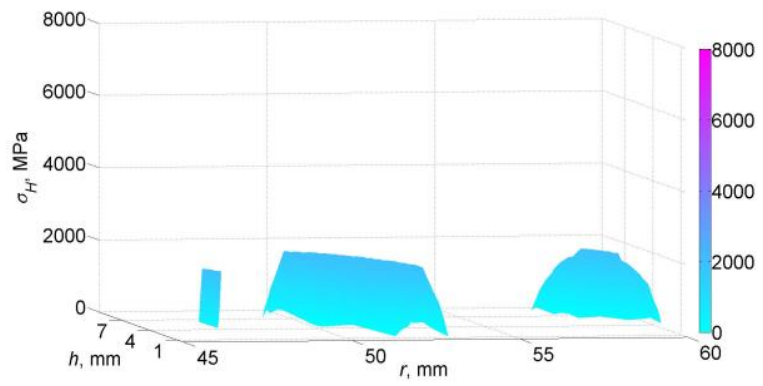

b)

Fig. 13. Distribution of $\sigma_{H}$ in the gear of gearbox RZAM-S500 for $f_{x p}=100 \mathrm{mcm}$.

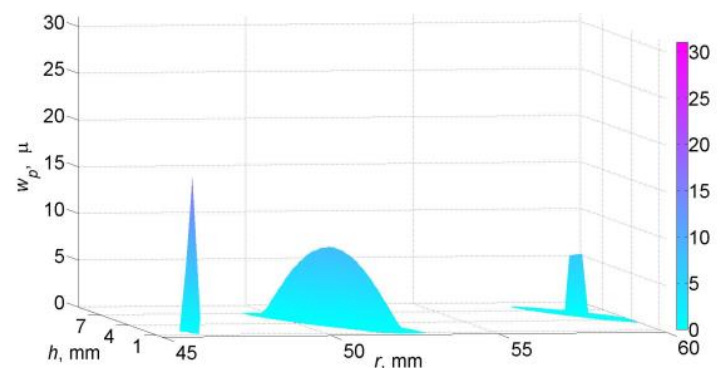

Fig. 14. Distribution of $w_{p}$ in the gear of gearbox P3AM-C-500 for $f_{x p}=100 \mathrm{mcm}$.

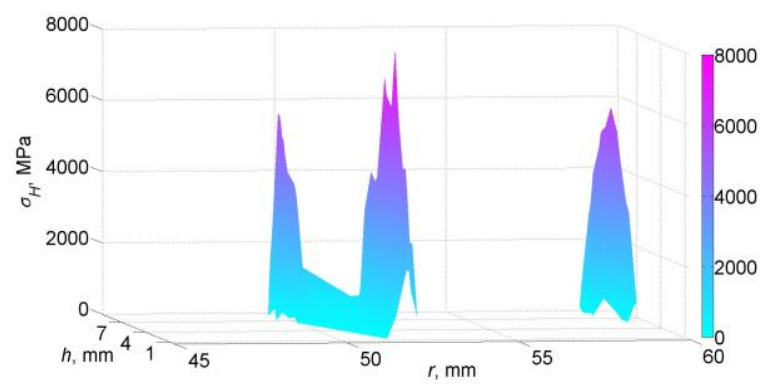

a)

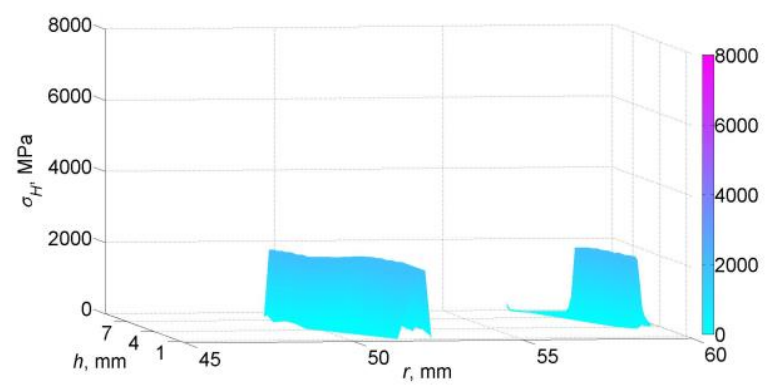

b)

Fig. 15. Distribution of $\sigma_{H}$ in the gear of gearbox RZAM-S500 for $f_{\text {fac }}=100 \mathrm{mcm}$.

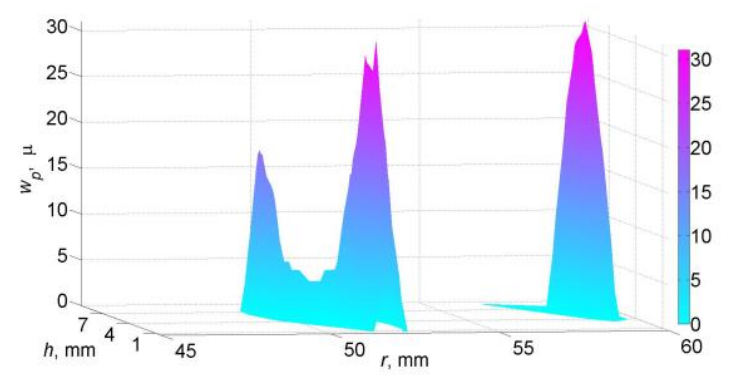

Fig. 16. Distribution of $w_{p}$ in the gear of gearbox RZA-S-500 for $f_{\text {fac }}=100 \mathrm{mcm}$.

\section{Analysis of results}

The obtained results give ground for the following conclusions:

1. The developed numerical algorithm of SSS analysis of a multi-pair spiroid gear with account of the elastoplastic character of contact is operational enough. For a multipair elastoplastically loaded spiroid gear with the cell dimensions $0.07 m_{x}$ ( 30 cells along the tooth height), the algorithm is reduced to the solution during the acceptable number of iterations (about 30 at average) with the mean discrepancy less than $0.5 \mathrm{mcm}$ (about $0.0001 m_{x}$ ).

2. As it was expected, the relevance of account of the elastoplastic character of contact rises with the increase in the level of gear loading. Thus, for heavy-loaded lowspeed gearboxes for pipeline valves, this account is urgent under the action of extreme static torques that exceed twice the maximum operating ones.

3. The elastic model for a heavy-loaded gear can have a very limited application: the maximum contact stress calculated by this model at maximum torques exceeds the allowable one by strain for not only gears but also for rolling bearings (3500 $\mathrm{MPa}$ [22]). It affirms the necessity of account of the elastoplastic contact.

4. The account of the plastic strain of contacting surfaces allows for specifying the loads acting on teeth, especially at the presence of large errors and strains of the structure in gears with high (more than 3-4) overlap ratio. In most cases, the plastic strain of $10-30 \mathrm{mcm}$ stipulates for unloading of the most loaded teeth (up to 10-15\%).

5. The researched gears of PV gearboxes showed high tolerance to the action of two-fold overloading torques even at the presence of relatively large errors (about 9-10 
degree of accuracy), having exhibited the uniform load distribution between tooth pairs.

\section{Conclusion}

The algorithm of load distribution analysis in a multipair spiroid gearing presented in this paper allows for assessing the area of the elastoplastic contact, the value of plastic strain of tooth flanks, to specify the values of loads acting on individual teeth. The calculation results must become the foundation for assessing the strength of a multi-pair heavy-loaded gear in accordance with the allowable contact strain of surfaces and the strength of worm threads and gearwheel teeth under the action of instant (including static one) overloading torques.

\section{References}

1. V. I. Goldfarb, D. V. Glavatskikh, E. S. Trubachev, A. S. Kuznetsov, E. V. Lukin, D. E. Ivanov, V. Yu. Puzanov, Spiroid gearboxes of pipeline valves (Moscow, Veche, 2011).

2. V. Goldfarb, In: Theory and Practice of Gearing and Transmissions, MMS 34 (Springer, 2016), 55-66

3. V. I. Goldfarb, E. S. Trubachev, A. S. Kuznetsov, J. Armaturostroenie, 1(94) (2015)

4. V. I. Goldfarb, In: Intelligent Systems in Production J, 15(1) (2017)

5. V. I. Goldfarb, E. S. Trubachev, V. V. Makarov, Valve World J, 11(6) (2006)

6. V. Abadjiev, E. Abadjieva, J Theoretical and Applied Mechanics, 46(3) (2016)

7. V. Abadjiev, On the Synthesis and Analysis of Spiroid Gears, Ph. D. Thesis (1984)

8. V. Abadjiev, Gearing Theory and Technical Applications of Hyperboloid Mechanisms, Sc. D. Thesis (2007)

9. V. Abadjiev, J. of Process Mechanical Engineering, 216 (E) (2002)

10. A. E. Volkov, G. I. Sheveleva, V. I. Medvedev, J. of Machinery Manufacture and Reliability, 2 (2003)

11. A. E. Volkov, V. I. Medvedev, M. A. Volosova, O. E. Zubelevich, In: Mechanism and Machine Theory, 86, 156-171 (2015)

12. E. Trubachev, A. Kuznetsov, A. Sannikov, In: Advanced Gear Engineering, MMS 51 (Springer, 2018), 45-72

13. E. S. Trubachev, A. S. Kuznetsov, Information Mathematics J. (2003)

14. https://cae-expert.ru/projects (accessed 02.04.2019).

15. S. I. Karatushin, D. A. Khramova, P. N. Bokuchava, Izvestiya Vysshykh Uchebnych Zavedenii J., 2(695) (2018)

16. S. I. Karatushin, Yu. A. Pleshanova, N. A. Byldyuk, P. N. Bokuchava, Izvestiya Vysshykh Uchebnych Zavedenii J., 12(669) (2015)
17. https://www.auma.com/en/products/multi-turngearboxes.. (accessed 02.04.2019).

18. https://www.rotork.com/en/products-andservices/gearboxes-and-valve-accessories (accessed 02.04.2019).

19. http://www.pro-gear.de/en/products/X-series (accessed 02.04.2019).

20. R. Müller, L. Schirmer, In : Proc. Int. Conf. on Gears, Garching/Munich, Germany (2017)

21. E. M. Tretyakov, Vestnik MGTU, Mashinostroenie, 4, 98-124 (2012)

22. L. Ya. Perel, Rolling bearings: analysis, design, and maintenance of supports (Moscow, Mashinostroenie, 1983) 